\title{
Tantangan Industri Farmasi Indonesia di Era Pandemik COVID-19
}

\author{
Ari Sri Windyaswari ${ }^{1}$, Faizal Hermanto ${ }^{1}$, Suci Narvikasari ${ }^{1}$, Soraya Riyanti ${ }^{1}$, \\ Akhirul Kahfi Syam', Catellya Febrinella ${ }^{2}$
}

\author{
${ }^{1}$ Fakultas Farmasi, Universitas Jenderal Achmad Yani \\ ${ }^{2}$ Pengurus Daerah Ikatan Apoteker Indonesia Jawa Barat \\ Penulis korespondensi: ari.sri.w@lecture.unjani.ac.id
}

\begin{abstract}
Abstrak: Situasi pandemik COVID-19 di Indonesia mempengaruhi beberapa sektor penting, diantaranya adalah sektor kesehatan. Farmasi sebagai salah satu garda penting di bidang kesehatan mempunyai tugas fungsi pokok untuk menyediakan obat yang aman, berkhasiat dan berkualitas. Industri farmasi merupakan bagian terdepan yang memiliki peranan penting tersebut sekaligus merupakan bagian terdepan yang terkena dampak dari situasi pandemik COVID-19. Tekanan untuk penemuan vaksin/obat baru sebagai antivirus COVID19 hingga produksi vitamin dan produk nutrisi lain sebagai upaya preventif untuk melindungi masyarakat Indonesia dari peningkatan penularan virus COVID-19 di Indonesia menghadapi berbagai kendala. Pembatasan Sosial Berskala Besar (PSBB), kegiatan karantina serta isolasi merupakan salah satu kendala di dalam bidang produksi. Disisi lain, permintaan akan produk obat meningkat tajam. Apoteker industri dan apoteker komunitas bekerja sama untuk memastikan ketersediaan dan efek terapi obat dapat digunakan oleh masyarakat Indonesia. Tujuan dilaksanakannya webinar ini adalah untuk mengubah paradigma permasalahan menjadi suatu tantangan yang harus diselesaikan oleh sejawat apoteker di seluruh Indonesia. Metode webinar dilaksanakan melalui penyampaian materi dan diskusi panel dari platform ZOOM dan youtube. Hasil post test yang dilaksanakan terhadap 1.700 peserta secara garis besar menunjukkan pemahaman dan kepedulian masyarakat dalam mengatasi berbagai permasalahan di bidang farmasi industry Indonesia.
\end{abstract}

Kata kunci: Apoteker, Industri Farmasi, COVID-19.

\begin{abstract}
The COVID-19 situation in Indonesia affects several important sectors, including the health sector. Pharmacy as one of the important divisions has its main function to provide safeness, efficaciousness and quality of drugs. The pharmaceutical industry has an important role to solve the problems. On the other hand, the direct impact of the COVID-19 situation on the pharmaceutical industry has decreased production. The discovery to find a new vaccinel drug as an antiviral for COVID19 is quite important Hence, the production of vitamins and other nutrients as a preventive effort to protect the Indonesian people really needs attention. The large-scale Social Restrictions (PSBB), 14-days-quarantine and isolation activities to reduce the risk may cause the production. Industrial and community pharmacists need to work together to ensure the health of Indonesian people, as well. The aim of the research is to change the paradigm of the problem into a challenge. The webinar method is carried out by delivering material and panel discussions from the ZOOM and YouTube platforms. The results of the post test conducted on 1,700 participants showed broad public understanding and concern in overcoming various problems in the Indonesian pharmaceutical industry.
\end{abstract}

Keywords: Pharmacists, Pharmaceutical Industry, COVID-19

Volume 1, Nomor 2, Oktober 2020 | 137 


\section{Pendahuluan}

Sejak akhir tahun 2019, telah teridentifikasi suatu novel virus korona (2019-nCoV) sebagai agen penginfeksi penyakit ringan hingga berat pada saluran pernafasan. Dikarenakan tingkat keseriusan penyakit yang disebabkan oleh virus patogen tersebut semakin meningkat, maka penamaan (2019-nCoV) diganti menjadi Severe Acute Respiratory Coronavirus Type 2"(SARS-CoV-2). Penyebaran virus ini dimulai dari episentrum pertama, kota Wuhan, provinsi Hubei, daratan Cina, hingga menjadi pandemi global. Berdasarkan data yang dihimpun, hingga 15 Juli 2020 wabah masih berlangsung di 213 negara di berbagai benua. Virus korona (SARS-CoV-2) telah menyebabkan jumlah kematian yang dramatis yaitu sekitar 580.000 kematian dan lebih dari 13 juta kasus diseluruh dunia. Hal ini berimbas pada berbagai sektor sosial dan ekonomi pada seluruh belahan dunia. Disisi lain virus korona (SARS-CoV2) telah mendorong beberapa perubahan pada sistem farmasi secara menyeluruh. Perubahan nyata dari berbagai aspek farmasi industri, regulasi dan distribusi serta pelayanan farmasi klinik melahirkan suatu tantangan baru untuk mengatasi pandemi COVID-19 di berbagai negara. (Bragazzi, 2020).

Penerapan kebiasaan baru disosialisasikan menyeluruh meliputi sosialisasi tata cara mencuci tangan yang benar, penggunaan pembersih tangan berbasis alkohol, pemakaian masker dan face shield serta alat pelindung diri (APD) bila diperlukan. Hal ini dilakukan untuk mencegah penumpukan di sarana kesehatan yang menyebabkan pengurangan tekanan terhadap tenaga kesehatan (dokter, apoteker, perawat), pengurangan pemakaian peralatan bantu (respirator dan ventilator) terhadap pasien COVID-19. (Balla, 2020).

Di Indonesia sekitar 55.000 kasus COVID-19 terkonfirmasi sebagai yang tertinggi di Asia Tenggara dan hampir 3.000 kematian di seluruh negeri pada akhir Juni 2020 . Untuk menekan penyebaran COVID-19 lebih lanjut, WHO menyatakan pentingnya menjaga jarak fisik dengan menjaga jarak minimal 1 meter dari satu sama lain, membatasi menghabiskan waktu di tempat keramaian atau kelompok, dan memakai masker wajah. Indonesia merekomendasikan anjuran untuk beraktivitas dari rumah sejak 15 Maret 2020 kemudian menerapkan Pembatasan Sosial Berskala Besar (PSBB) pada tanggal 10 April 2020, sebagai tanggapan atas kasus COVID-19 yang melonjak secara nasional. Selama PSBB, transportasi umum, perjalanan dan tempattempat umum dibatasi atau ditutup, orang didorong untuk bekerja atau belajar dari rumah, dan pertemuan besar (pernikahan dan kegiatan ibadah) dilarang untuk membatasi kontak fisik atau sosial langsung. (Siste, 2020). 
Obat adalah bahan atau paduan bahan, termasuk produk biologi yang digunakan untuk mempengaruhi atau menyelidiki sistem fisiologi atau keadaan patologi dalam rangka penetapan diagnosis, pencegahan, penyembuhan, pemulihan, peningkatan kesehatan dan kontrasepsi untuk manusia (Kementerian Kesehatan, 2016).

Suatu obat yang akan didistribusikan kepada pengguna harus memiliki aspek aman, berkhasiat serta berkualitas. Penyimpanan merupakan salah satu aspek kualitas dalam suatu obat. Penyimpanan adalah kegiatan pengamanan terhadap obat-obatan yang diterima agar aman, terhindar dari kerusak fisik dan kimia sehingga mutu obat tetap terjamin dengan baik (Departemen Kesehatan Republik Indonesia, 2002). Tujuan dari penyimpanan obat yang baik adalah mempertahankan mutu obat dari kerusakan akibat dari penyimpanan yang tidak benar, obat dapat awet yaitu obat tidak berubah baunya, warnanya, bentuknya, ukurannya serta fungsinya (Departemen Kesehatan Republik Indonesia, 2002; Kappauf et al., 2012).

Mengingat hingga saat ini belum ada produk vaksin dan obat yang efektif untuk mencegah dan mengobati infeksi COVID-19, setiap negara telah menerapkan pembatasan perilaku non farmakologis (NPI) meliputi penutupan usaha sekunder, penutupan sekolah dan universitas, pembatasan perjalanan, meliputi pembatalan penerbangan domestik dan internasional, isolasi diri, pembatasan sosial skala besar, karantina mandiri serta isolasi suatu wilayah untuk menekan penyebaran wabah COVID-19. (Balla, 2020)

Pembatasan perilaku non farmakologis menyebabkan pelaku usaha bidang farmasi mengalami kesulitan dalam penyediaan bahan baku, produksi hingga pendistribusian obat kepada masyarakat. Di sisi lain, banyak industri farmasi yang mengurangi jam kerja dan jumlah personalia yang terlibat untuk mencegah terjadinya resiko penularan wabah COVID-19. Disisi lain, obat merupakan hal penting yang diperlukan oleh tenaga kesehatan dan masyarakat sebagai upaya preventif ataupun kuratif. (Kappauf, 2019)

Tantangan industri farmasi di era pandemik COVID-19 memberikan beberapa peluang dan berbagai cara penyelesaian untuk mencegah terjadinya kolaps pada industri farmasi nasional. Dengan adanya kegiatan Webinar mengenai tantangan industri farmasi di era pandemik COVID-19 diharapkan dapat menambah ilmu pengetahuan, pemahaman dan berbagai permasalahan pada industri farmasi nasional. 


\section{Metode}

Metode pengabdian masyarakat dilaksanakan melalui Webinar Nasional yang diikuti oleh peserta dalam dan luar negeri. Untuk mengukur tingkat pengetahuan masyarakat mengenai tantangan dan peluang industri farmasi di era pandemik COVID-19, dilakukan evaluasi pertanyaan (post test) setelah acara webinar selesai. Bentuk pertanyaan yang diberikan sebanyak 10 pertanyaan dengan topik seputar tantangan dan peluang industri farmasi Indonesia di era pandemik COVID-19. Analisis data meliputi data distribusi responden, analisis jumlah pertanyaan yang benar setelah pelaksanaan seminar. Peserta yang lulus post test dengan nilai minimum 80 akan mendapatkan sertifikat SKP dari organisasi profesi Ikatan Profesi Apoteker (IAI) Pengurus Daerah Jawa Barat.

Kegiatan ini dilaksanakan pada tanggal 4 Juli 2020 pukul 09:00-11:30 WIB menggunakan 2 platform, yaitu platform ZOOM dan platform Youtube. Sebanyak 1.400 peserta dengan penyebaran domisili di berbagai pulau Indonesia mengikuti Webinar melalui platform ZOOM dan sebanyak 200 orang mengikuti Webinar melalui link streaming Youtube. Kegiatan ini dipublikasikan pada media cetak dan elektronik regional dan nasional.

\section{Hasil dan Diskusi}

Tujuan pelaksanaan Webinar Nasional Tantangan Industri Farmasi Indonesia di Era Pandemik adalah memberikan informasi dan solusi permasalahan bagi sejawat di bidang farmasi industri dalam menghadapi era pandemik COVID-19. Hasil paparan narasumber yang disampaikan selama proses webinar berlangsung harus dapat menjawab tantangan yang harus dihadapi oleh para sejawat. Implementasi sejawat untuk menerapkan perubahan dan antisipasi dalam farmasi industri adalah jawaban dari keberhasilan webinar ini.

Sasaran peserta Webinar adalah mahasiswa tingkat akhir Program Studi Profesi Apoteker yang akan terjun ke masyarakat di tengah kondisi pandemik COVID 19, para sejawat praktisi industri, sejawat dibidang regulator atau institusi pemerintahan, sejawat di bidang distribusi dan sejawat dibidang farmasi komunitas. Data distribusi peserta Webinar Nasional Tantangan industri farmasi di era pandemik COVID-19 disajikan pada Gambar 1.

Dari data pada Gambar 1 dapat dilihat peta persebaran peserta Webinar Nasional ini telah menjawab sasaran pengabdian masyarakat. Sebanyak 4 aspek penting meliputi jenis kelamin, demografi, profesi dan usia memberikan gambaran kaitan antara aspek dengan tujuan Webinar. Data jenis kelamin menggambarkan rasio pria dan wanita yang bergerak atau memiliki 
peminatan dalam bidang farmasi industri. Dapat disimpulkan sebanyak $43 \%$ pria dan $57 \%$ wanita memiliki permasalahan atau ingin mengetahui tantangan yang terjadi di masa pandemic COVID-19 terhadap dunia farmasi industri. Peta demografi menunjukkan persebaran peserta dari bagian barat hingga bagian timur Indonesia. Hal ini memberikan keuntungan karena sosialisasi mengenai tantangan dan peluang industri farmasi di masa pandemik COVID-19 dapat diterapkan dan diimplementasikan secara langsung untuk mencegah penularan wabah COVID-19 di wilayah domisili. Usia menggambarkan tingkat produktivitas seseorang. Sebanyak $87 \%$ peserta merupakan mahasiswa, hal ini memberikan keuntungan agar mereka dapat merancang strategi untuk persiapan melamar pekerjaan di masa pandemik COVID-19. Profesi merupakan salah satu aspek yang menarik. Walaupun didominasi oleh apoteker sebanyak 90\%, dokter dan tenaga kesehatan lain ternyata memiliki ketertarikan terhadap bidang farmasi industri. Hal ini dikarenakan ada kaitan langsung antara profesi dengan ketersediaan obat yang akan diproduksi dan pasien yang akan menggunakan obat tersebut.

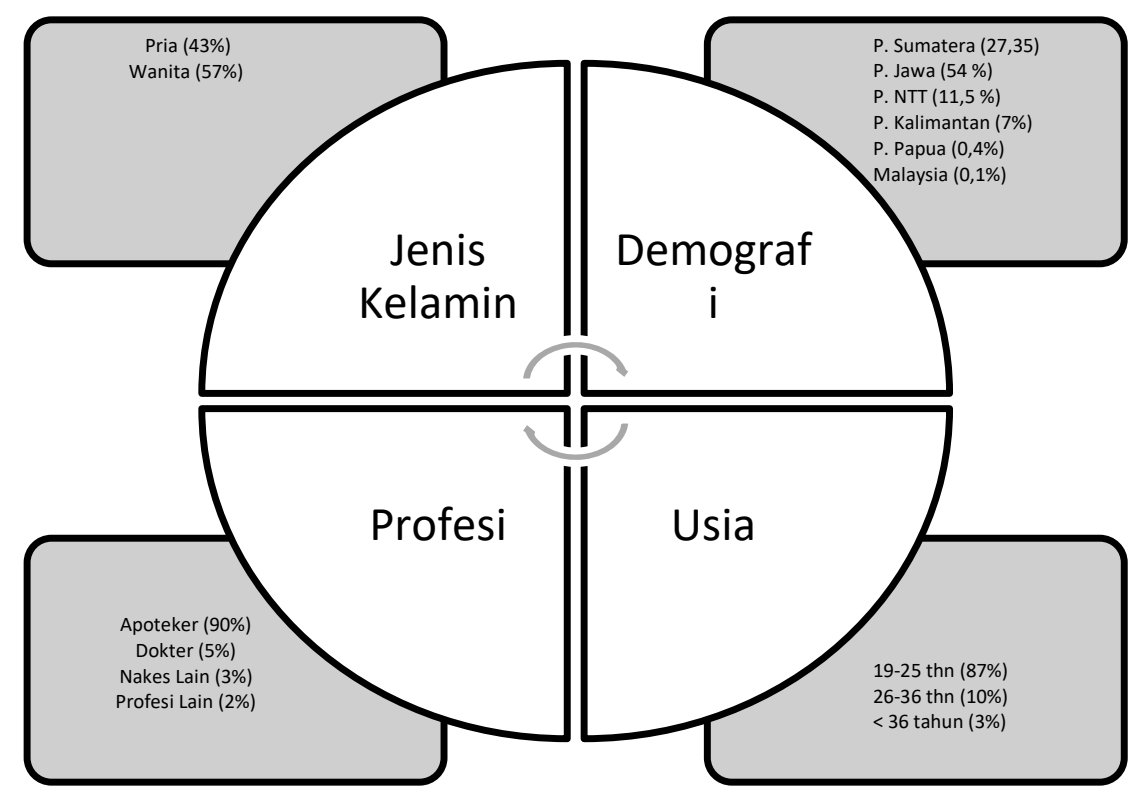

Gambar 1. Diagram penyebaran peserta Webinar

Ukuran keberhasilan kegiatan Webinar melalui penilaian terhadap ketepatan jawaban yang dijawab oleh peserta webinar dan disajikan dalam Tabel 1.

Tabel 1. Penilaian Kuesioner

\begin{tabular}{|c|c|c|}
\hline No. & Persentase Kebenaran Jawaban Peserta & Rentang nilai \\
\hline 1. & $10 \%$ & $80-82$ \\
\hline 2. & $80 \%$ & $83-85$ \\
\hline 3. & $5 \%$ & $86-89$ \\
\hline 4. & $5 \%$ & $<89$ \\
\hline
\end{tabular}


Dari Tabel 1 dapat dilihat bahwa secara umum sasaran dan tujuan Webinar telah tercapai. Sebagian besar peserta sudah menjawab dengan baik sehingga rentang nilai minimum yang dipersyaratkan untuk memperoleh sertifikat yang terintegrasi dengan nilai Satuan Kredit Profesi (SKS). Hasil publikasi pada beberapa media cetak dan elektronik meliputi Pikiran Rakyat (pikiranrakyat.com); Pindainews (pindainews.com); Galamedia (galamedia.com); Info Bandung (infobandung.com); Kantor berita RMOLJABAR (rmoljabar.id) dan LIFEBITZ (lifebitz), disajikan pada Gambar 2. Hasil publikasi pada beberapa media cetak dan elektronik regional dan nasional merupakan upaya untuk menyampaikan informasi seluas-luasnya kepada masyarakat, memberikan pandangan mengenai situasi terkini di Indonesia terutama di bidang farmasi industri serta menjawab tantangan di masa pandemic COVID-19 ini.

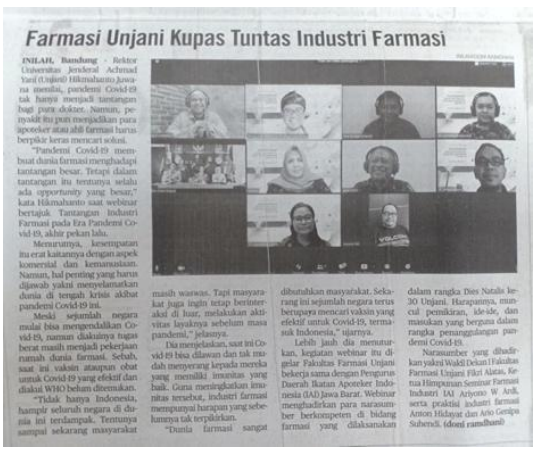

(a)

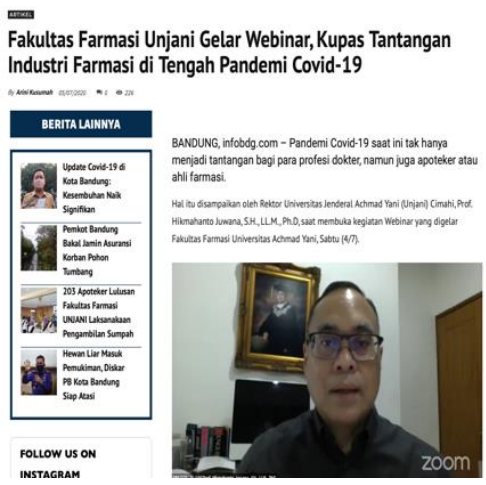

(d)

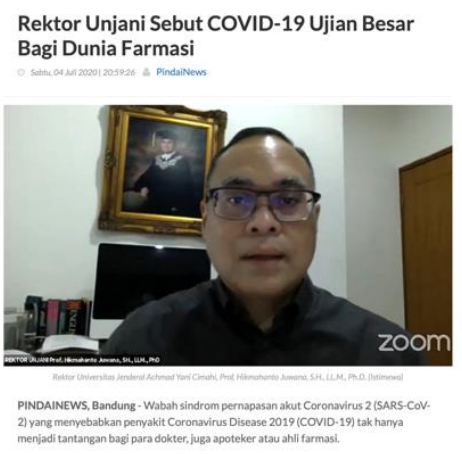

(b)

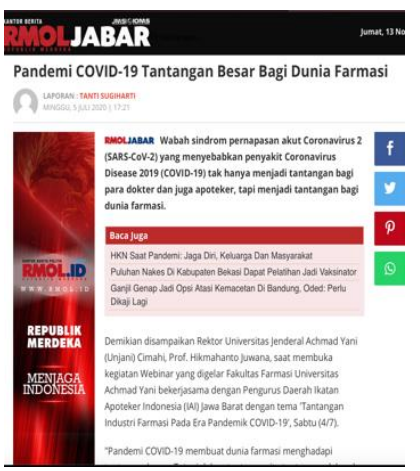

(e)

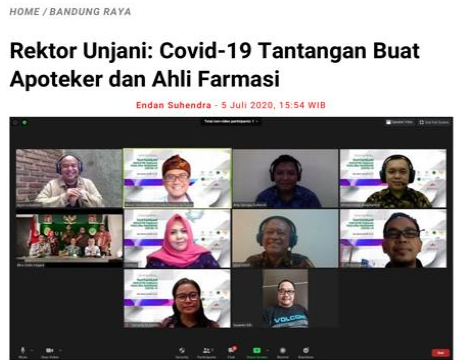

(c)

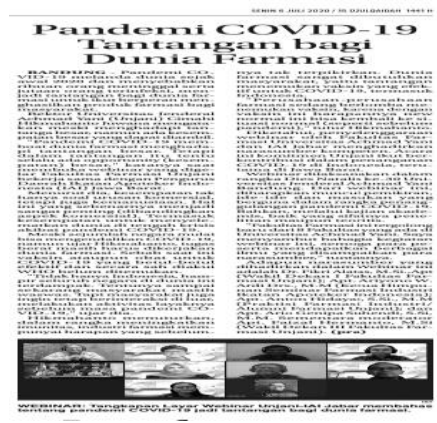

(f)

Gambar 2. Hasil Publikasi Webinar Nasional, (a) pikiranrakyat.com, (b) pindainews.com, ( c)galamedia.com, d) infobandung.com, (e) rmoljabar.id, (f) lifebitz.com

\section{Kesimpulan}

Dari hasil Webinar diketahui permasalahan yang terjadi di farmasi industri dan upaya webinar ini untuk memberikan jawaban dari salah satu permasalahan masyarakat akibat pandemic COVID-19 sudah tercapai. 


\section{Ucapan Terima Kasih}

Ucapan terima kasih kepada Lembaga Penelitian \& Pengabdian pada Masyarakat (LPPM) Universitas Jenderal Achmad Yani yang telah mendanai kegiatan penyuluhan ini, serta kepada seluruh narasumber yang berkenan hadir untuk berbagi motivasi dan ide pada Webinar Nasional: Tantangan Industri Farmasi menghadapi Era Pandemik COVID-19.

\section{Daftar Referensi}

Aldila D. 2020. Analyzing the impact of the media campaign and rapid testing for COVID-19 as an optimal control problem in East Java Indonesia. Chaos Solitons Fractals, Dec. 141:110364. doi: 10.1016/j.chaos.2020.110364. Epub 2020 Oct 15. PMID: 33082625; PMCID: PMC7561305.

Balla, M., Merugu, G.P., Patel, M., Koduri, N.M., Gayam, V., Adapa, S., Naramala, S., Konala, V.M. 2020. COVID-19, Modern Pandemic: A Systematic Review From Front-Line Health Care Providers' Perspective. J. Clin. Med. Res. 12, 215-229.

Bragazzi NL, Mansour M, Bonsignore A, Ciliberti R. 2020. The Role of Hospital and Community Pharmacists in the Management of COVID-19: Towards an Expanded Definition of the Roles, Responsibilities, and Duties of the Pharmacist. Pharmacy (Basel), 8(3), 140. doi: 10.3390/pharmacy8030140. PMID: 32784696; PMCID: PMC7558051.

Efendie B, Abdullah I, Yusuf E. 2020. Impact of COVID-19 Pandemic on Pharmacy Education in Malaysia and Indonesia. Sr Care Pharm., 35(11), 484-486. doi: 10.4140/TCP.n.2020.484.. PMID: 33121570.

Departemen Kesehatan Republik Indonesia. (2002). Pedoman Pengelolaan Obat Publik dan Perbekalan Kesehatan.

Siste K., Hanafi, E., Sen L.T., Christian, H., Adrian, Siswidiani, L.P., Limawan, A.P., Murtani, B.J., Suwartono, C. 2020. The Impact of Physical Distancing and Associated Factors Towards Internet Addiction Among Adults in Indonesia During COVID-19 Pandemic: A Nationwide Web-Based Study. Front Psychiatry., 11, 580977. doi: 10.3389/fpsyt.2020.580977. PMID: 33101092; PMCID: PMC7495250.

Rewari BB, Mangadan-Konath N, Sharma M. Impact of COVID-19 on the global supply chain of antiretroviral drugs: a rapid survey of Indian manufacturers. WHO South East Asia J Public Health. 2020 Sep;9(2):126-133. doi: 10.4103/2224-3151.294306. PMID: 32978345.

Kappauf, J., Lauterbach, B., \& Koch, M. 2012. Logistic Core Operations with SAP. Logistic Core Operations with SAP. https://doi.org/10.1007/978-3-642-18202-0.

Kementerian Kesehatan. (2016). Standar Pelayanan Kefarmasian Di Apotek. Kementerian Kesehatan Republik Indonesia. https://doi.org/10.5151/cidi2017-060. 